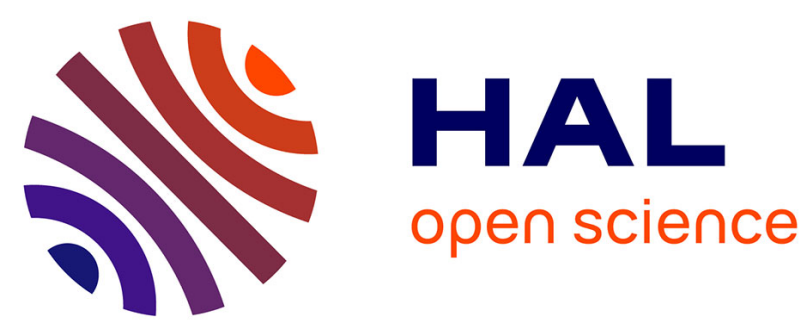

\title{
Epitaxial MOVPE growth of highly c-axis oriented InGaN/GaN films on ZnO-buffered Si (111) substrates
}

A. Ougazzaden, D. J. Rogers, F. Hosseini Teherani, G. Orsal, T. Moudakir, S. Gautier, V. E. Sandana, F. Jomard, M. Abid, M. Molinari, et al.

\section{- To cite this version:}

A. Ougazzaden, D. J. Rogers, F. Hosseini Teherani, G. Orsal, T. Moudakir, et al.. Epitaxial MOVPE growth of highly c-axis oriented InGaN/GaN films on ZnO-buffered Si (111) substrates. SPIE Photonic West, Jan 2010, San Francisco, United States. pp.76031D-1, 10.1117/12.846664 . hal-00554294

\author{
HAL Id: hal-00554294 \\ https://hal.science/hal-00554294
}

Submitted on 2 Dec 2021

HAL is a multi-disciplinary open access archive for the deposit and dissemination of scientific research documents, whether they are published or not. The documents may come from teaching and research institutions in France or abroad, or from public or private research centers.
L'archive ouverte pluridisciplinaire HAL, est destinée au dépôt et à la diffusion de documents scientifiques de niveau recherche, publiés ou non, émanant des établissements d'enseignement et de recherche français ou étrangers, des laboratoires publics ou privés.

\section{(ㅇ)(1) $\$$}

Distributed under a Creative Commons Attribution - NonCommerciall 4.0 International 


\title{
Epitaxial MOVPE growth of highly c-axis oriented InGaN/GaN films on ZnO- buffered Si (111) substrates
}

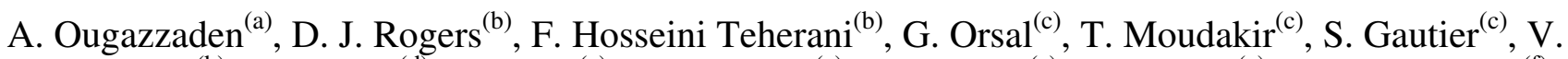

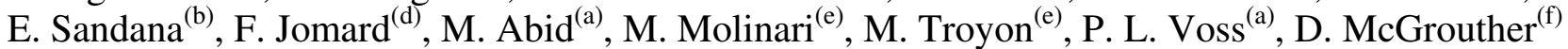 \\ \& J. N. Chapman ${ }^{(\mathrm{f})}$

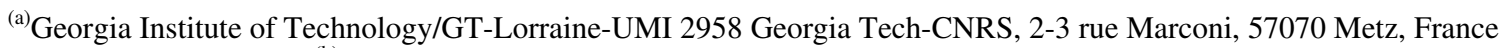 \\ (b) Nanovation SARL, 103 bis Rue de Versailles, Orsay, 91400, France \\ ${ }^{(c)}$ LMOPS - UMR CNRS 7132, Université de Metz et SUPELEC, 2 rue Edouard Belin, 57070 METZ, France \\ ${ }^{(\mathrm{d})}$ GEMAC, Université de Versailles-Saint-Quentin1, place Aristide Briand, 92195 Meudon Cedex France \\ ${ }^{(e)}$ LMEN, University of Reims Champagne-Ardennes, 21 rue Clement Ader, 51685 Reims, France \\ ${ }^{(f)}$ Department of Physics and Astronomy, University of Glasgow, G12 8QQ, Scotland. \\ Corresponding author : aougazza@georgiatech-metz.fr
}

\begin{abstract}
InGaN/GaN layers were grown on $\mathrm{ZnO}$-buffered $\mathrm{Si}$ (111) substrates by metalorganic vapour phase epitaxy (MOVPE). The dissociation of $\mathrm{ZnO}$ observed during conventional MOVPE growth of InGaN/GaN was combated through the use of a low pressure/temperature MOVPE approach with $\mathrm{N}_{2}$ as a carrier gas and dimethylhydrazine added to the ammonia (nitrogen precursor) in order to enhance the concentration of atomic nitrogen at relatively low temperature. Electron Microscopy of cross-sections, High Resolution X-Ray Diffraction (HR-XRD), secondary ion mass spectroscopy and cathodoluminescence studies suggested that single phase wurtzite InGaN layers with between about 17.5 and $21.5 \%$ indium were grown epitaxially, with no evidence of back-etching of the $\mathrm{ZnO}$ templates. HR-XRD revealed highly pronounced c-axis texture for both the InGaN/GaN and $\mathrm{ZnO}$. Immersion in dilute nitric acid dissolved the $\mathrm{ZnO}$ such that the InGaN/GaN could be lifted-off from the substrate.
\end{abstract}

Keywords: metalorganic vapour phase epitaxy, InGaN, pulsed laser deposition, $\mathrm{ZnO}$, Si substrate, lift-off

\section{INTRODUCTION}

Recently, the Gallium Nitride $(\mathrm{GaN})$ and Zinc Oxide $(\mathrm{ZnO})$ materials systems have attracted considerable attention because of their use in a broad range of emerging applications including lightemitting diodes [1-2] and solar cells [3-4]. GaN and $\mathrm{ZnO}$ are similar in that they have direct wide bandgaps, wurtzite crystal structure, high thermal stability and comparable thermal expansion coefficients. GaN has the advantage, however, of a mature know-how for p-type doping, while $\mathrm{ZnO}$ has proven to be more crystallographically compliant to non-native substrates than GaN. With a view to exploiting both of these strong points, $\mathrm{ZnO}$ layers have been proposed as buffer layers for the regrowth of GaN-based p-n devices on amorphous and mismatched substrates [5-9]. 
Alloying with In is important for engineering a reduced bandgap in GaN and thus facilitating quantum wells and devices which can function over the whole visible range. Previously, epitaxial growth of InGaN on $\mathrm{ZnO}$ has been reported on sapphire $\left(\mathrm{Al}_{2} \mathrm{O}_{3}\right)$ substrates [10-11]. However, $\mathrm{Al}_{2} \mathrm{O}_{3}$ substrates are insulating, limited in size and relatively expensive. Silicon ( $\mathrm{Si}$ ) substrates, on the other hand, are cheaper, available in larger formats, have higher thermal/electrical conductivities and offer the potential for integration with mature Si-based electronics [12-13]. In this paper, we investigate the growth of InGaN/GaN on $\mathrm{ZnO}$-buffered $\mathrm{Si}$ (111) substrates using metalorganic vapour phase epitaxy (MOVPE), which is the dominant growth technology for InGaN-based materials and devices.

One serious obstacle to the epitaxy of $\mathrm{InGaN}$ on $\mathrm{ZnO}$ is the stability of $\mathrm{ZnO}$ in the MOVPE process. In particular, exposure to ammonia $\left(\mathrm{NH}_{3}\right)$ precursor and $\mathrm{H}_{2}$ carrier gas at growth temperatures over about $650^{\circ} \mathrm{C}$ results in the decomposition of the $\mathrm{ZnO}$ [14-15]. This can lead to the formation of interfacial layers/compounds, poor epitaxy and the unintentional incorporation of liberated $\mathrm{Zn}$ and $\mathrm{O}$ into the InGaN epilayer, which is detrimental for the optical and electrical properties.

\section{EXPERIMENT}

$\mathrm{ZnO}$ thin film templates were grown on 2-inch diameter Si (111) substrates using Pulsed Laser Deposition (PLD) with a Coherent KrF excimer laser (248nm) [5]. PLD was chosen because the high adatom mobility in this growth technique allows the $\mathrm{ZnO}$ to crystallise readily on amorphous substrates, such as the native $\mathrm{SiO}_{2}$ passivation layer on the surface of the Si substrate. $40 \mathrm{~nm}$ thick $\mathrm{GaN}$ and InGaN layers (of various thicknesses) were then grown on the $\mathrm{ZnO}$ films using a low pressure, T-shaped, MOVPE reactor [16] with Trimethylgallium (TMG) as the Ga source and Trimethylindium (TMIn) as the In source. A combination of $\mathrm{NH}_{3}$ and Dimethylhydrazine (DMHY) was used as a source of atomic nitrogen. DMHY was added because of its' low decomposition temperature, which enhances the concentration of atomic nitrogen in the gas phase compared to $\mathrm{NH}_{3}$ alone, allowing GaN growth at lower temperatures. Nitrogen was employed as a carrier gas [17] during the whole growth process, in order to avoid etching of the $\mathrm{ZnO}$ surface and ensure In incorporation [18]. The impact of In content was studied by adjusting the TMIn flow at constant TMGa flow.

The surface roughness and growth rate of InGaN layers were monitored during the growth using insitu reflectometry. Images of fracture cross-sectional samples were obtained using a Hitachi S-4800 field-emission scanning electron microscope (SEM). For transmission electron microscopy (TEM) investigation, cross-sectional samples were prepared using the in-situ liftout technique in a Dualbeam FIB (FEI Nova Nanolab 200). High resolution (HR-TEM) imaging was performed using an FEI Tecnai F20 equipped with a field emission gun source operated at $200 \mathrm{keV}$. The crystalline quality and indium composition of the InGaN layers were characterized by high resolution $\mathrm{x}$-ray diffraction (HR-XRD), using $\mathrm{Cu} \mathrm{K}_{\alpha}$ radiation in Panalytical MRD-Pro system equipped with a hybrid monochromator.

Concentration profiles of $\mathrm{In}, \mathrm{Ga}, \mathrm{N}$ and $\mathrm{Zn}$ along the growth direction were obtained by MCs+ Secondary Ion Mass Spectroscopy (SIMS) in a Cameca IMS4F system. The primary (incident) ions were 133Cs+ with an impact energy of $5.5 \mathrm{keV}$. Positively charged secondary ions were detected. The optical properties of the InGaN/GaN/ZnO were studied using a home-made cathodoluminescence (CL) system in an SEM [19]. 


\section{RESULTS \& DISCUSSION}

Figure 1 shows an SEM image of a fracture cross-section of an InGaN/GaN/ZnO/Si sample with approximately $21.5 \% \mathrm{In}$. The sample shows continuous InGaN/GaN and $\mathrm{ZnO}$ layers. A well-defined interface between $\mathrm{ZnO}$ and $\mathrm{GaN}$ can be clearly observed but the InGaN/GaN interface is not obvious. The thicknesses of the $\mathrm{InGaN} / \mathrm{GaN}$ and $\mathrm{ZnO}$ are about $180 \mathrm{~nm}$ and $140 \mathrm{~nm}$, respectively.

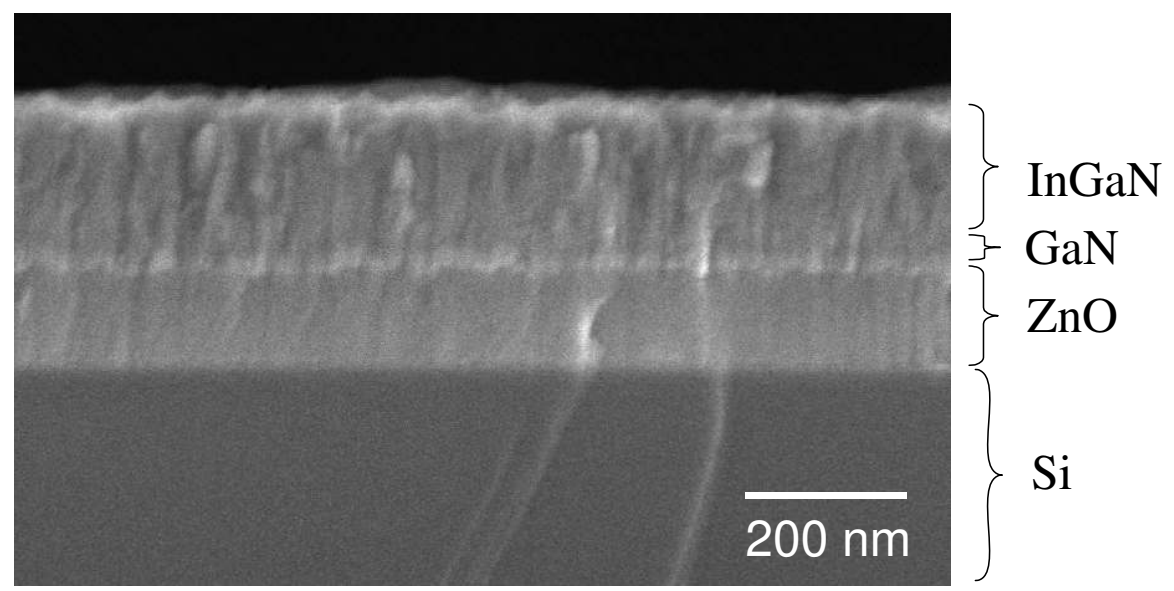

Figure 1. SEM fracture cross-section image of the $\mathrm{InGaN} / \mathrm{GaN} / \mathrm{ZnO} / \mathrm{Si}$ heterostructure.

Figure 2 shows a HR-TEM image of the $\mathrm{ZnO} / \mathrm{Si}$ interface. In this image, the regular lattice fringes in the $\mathrm{Si}$ substrate are interrupted at the interface with the $\mathrm{ZnO}$ due to the presence of the amorphous $\mathrm{SiO}_{2}$ overlayer ( $\sim 3 \mathrm{~nm}$ thick). The subsequent $\mathrm{ZnO}$ layer shows established lattice fringes after only $2 \mathrm{~nm}$ of growth, confirming the capacity of PLD-grown $\mathrm{ZnO}$ to crystallise on amorphous substrates.

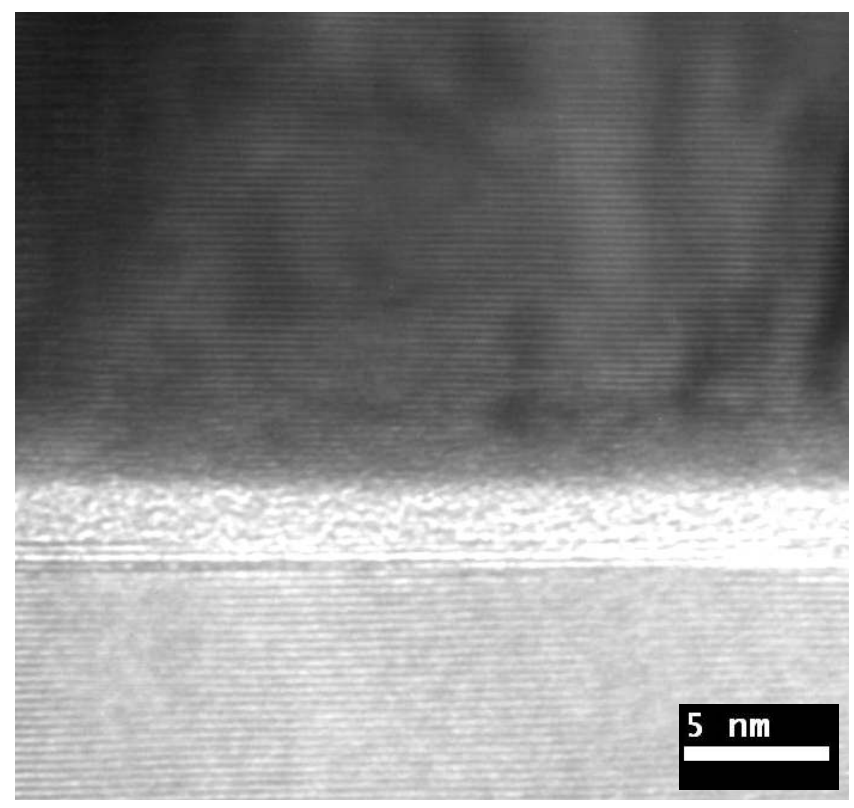

Figure 2. A HR-TEM image of the interface between the PLD-grown ZnO layer and the Si substrate. 
Figure 3 shows a HR-TEM image of the interfaces between the InGaN, GaN and ZnO layers plus the result of a Fast Fourier Transform (FFT) analysis.
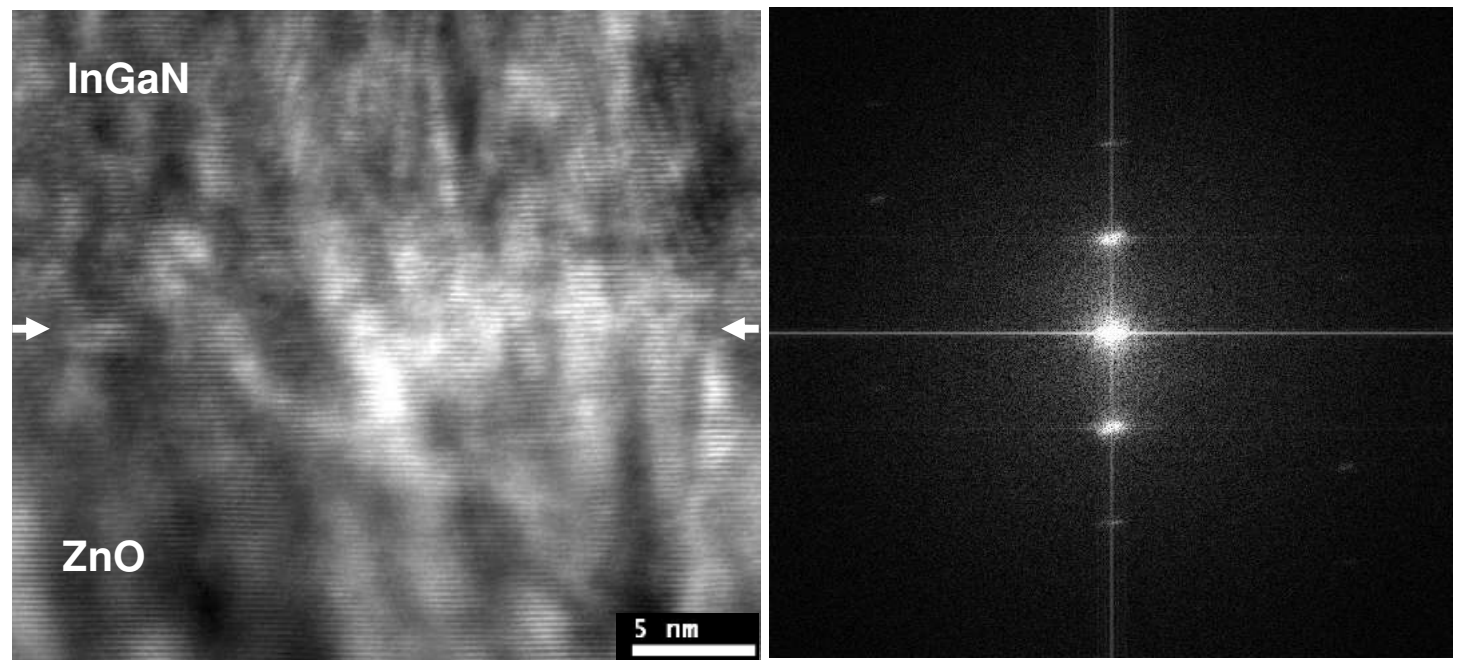

Figure 3. A HR-TEM image of the InGaN/GaN/ZnO interfaces plus a FFT analysis of the image (the arrows, in the former, suggest the position of $\mathrm{GaN} / \mathrm{ZnO}$ interface).

The image shows continuous lattice fringes across the InGaN/GaN/ZnO interfaces, with no evidence of a misfit layer, or any interfacial compounds. The FFT confirms that both the lattice plane alignment and lattice spacing are similar in the InGaN/GaN and $\mathrm{ZnO}$ layers. Thus the TEM studies suggest that there has been epitaxial growth.

Figure 4 shows the XRD $2 \theta-\omega$ scans as a function of TMIn/III ratio during growth.

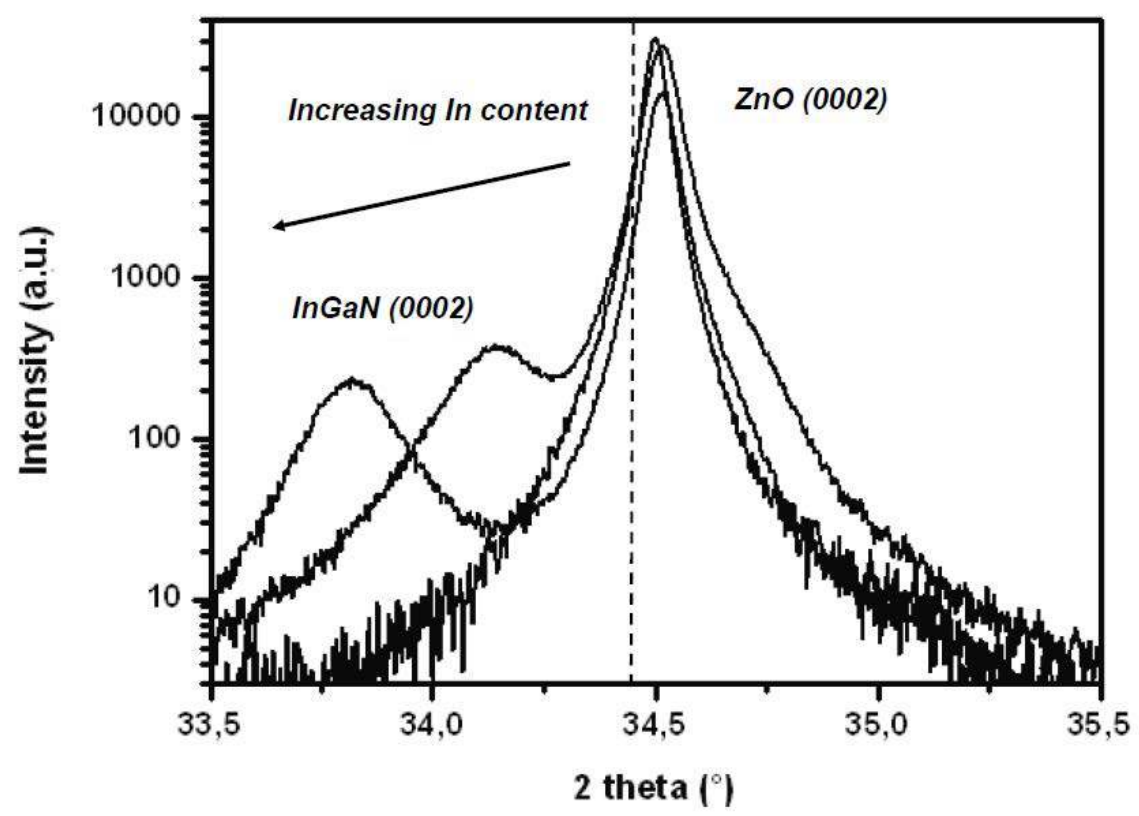

Figure 4. XRD $2 \theta-\omega$ scans of the (0002) peak for $\mathrm{ZnO} / \mathrm{Si}$ and the $\mathrm{InGaN} / \mathrm{GaN} / \mathrm{ZnO} / \mathrm{Si}$ with varying In contents. The dashed line shows the peak position $\left(34.43^{\circ}\right)$ for a $\mathrm{ZnO}$ powder reference sample. 
XRD study revealed the $\mathrm{InGaN} / \mathrm{GaN} / \mathrm{ZnO}$ layers to have single-phase wurtzite structure with strong c-axis orientation. The scans in Figure 4 present two distinct peaks, which were indexed as the (0002) peaks of the $\mathrm{ZnO}$ and the InGaN. An increase of the TMIn/III ratio led to a shift of the InGaN peak to lower angle and thus a higher out-of-plane "c" lattice parameter. The scans in Figure 4 also exhibited a small shoulder on the right of the $\mathrm{ZnO}$ peak, which was not visible in the XRD scans for the $\mathrm{ZnO}$ films prior to InGaN/GaN growth. This shoulder might be from the GaN layer. The concentration of In in the InGaN layer with higher In content (peak on left) was calculated from the (0002) InGaN peak position via Vegard's law to be about 21.5\%. The (0002) ZnO peaks for all samples grown on $\mathrm{Si}$ were observed to be shifted to a higher $2 \theta$ angle than expected for bulk $\mathrm{ZnO}$, which suggests that they were under tensile strain in the a-plane. This has been reported elsewhere for $\mathrm{ZnO}$ grown on $\mathrm{Si}$ substrates [20]. After InGaN/GaN growth, the $\mathrm{ZnO}$ peaks shifted slightly higher in $2 \theta$ (Figure 4). Thus the $\mathrm{ZnO}$ films absorbed some stress (tensile in this case) from the InGaN/GaN layers (as was observed in previous experiments on the MOVPE growth of GaN on $\left.\mathrm{ZnO} / \mathrm{c}-\mathrm{Al}_{2} \mathrm{O}_{3}[6]\right)$.

Figure 5 shows the SIMS concentration profiles for $\mathrm{Ga}$, In, $\mathrm{N}$ and $\mathrm{Zn}$ along the growth direction (in a sample with a thicker $\mathrm{ZnO}$ layer than that shown in Figure 1). The profile for $\mathrm{Zn}$ indicates some diffusion of $\mathrm{Zn}$ into the InGaN/GaN near the GaN/ZnO interface [8-9].

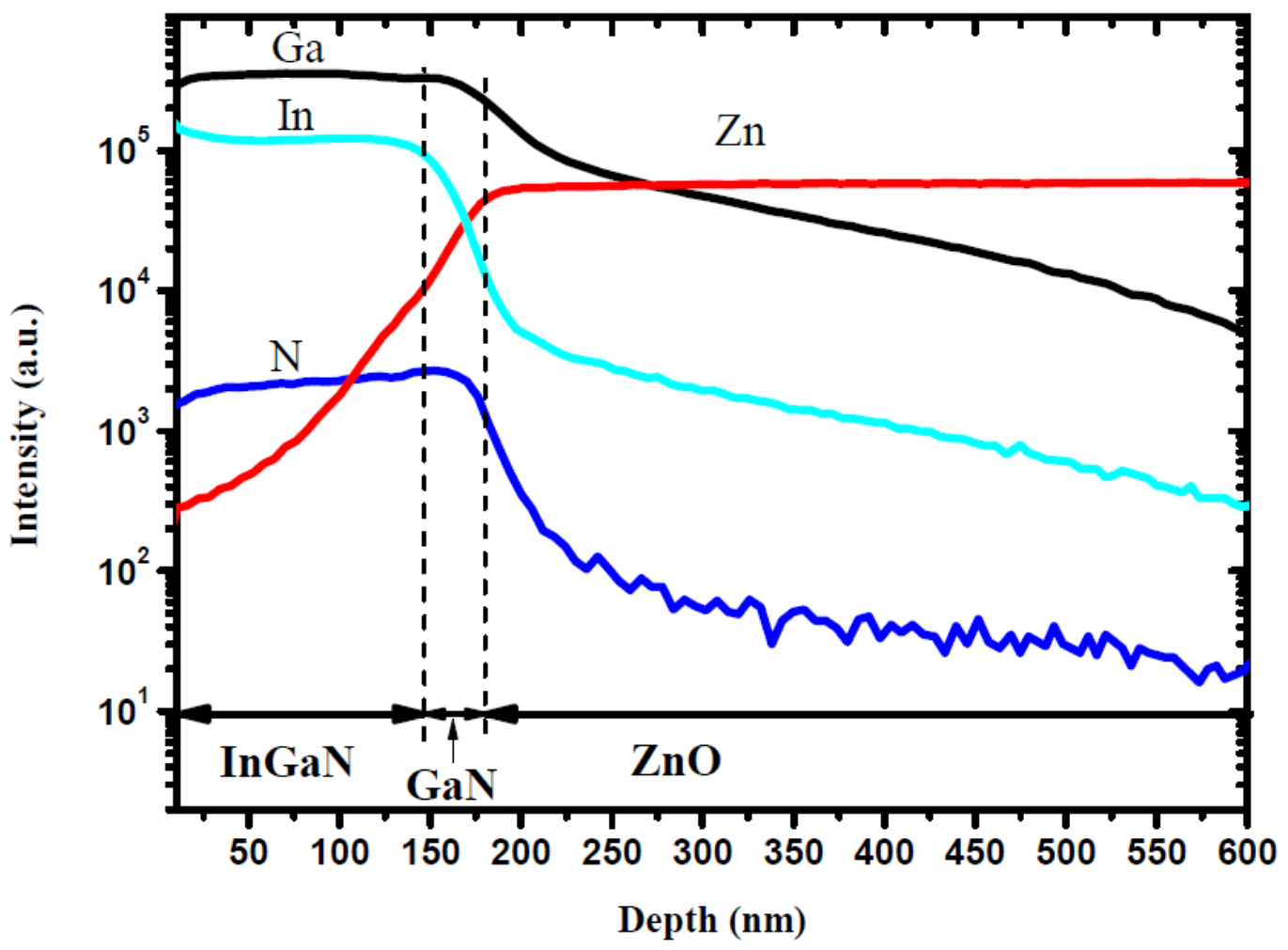

Figure 5. SIMS elemental concentration depth profiles for the $\mathrm{Zn}, \mathrm{Ga}, \mathrm{N}$ and In signals for the InGaN/GaN/ZnO-buffered $\mathrm{Si}$ (log. scale). It should be noted that the tails in the concentration profiles for $\mathrm{In}, \mathrm{Ga}$, and $\mathrm{N}$, which extend into the $\mathrm{ZnO}$, are probably artifacts due to residual particles of $\mathrm{InGaN}$ in the probe crater. 
Figure 6 shows a normalized, room temperature (RT), CL spectrum plus a Monte Carlo simulation of the respective primary and back-scattered electron diffusion.
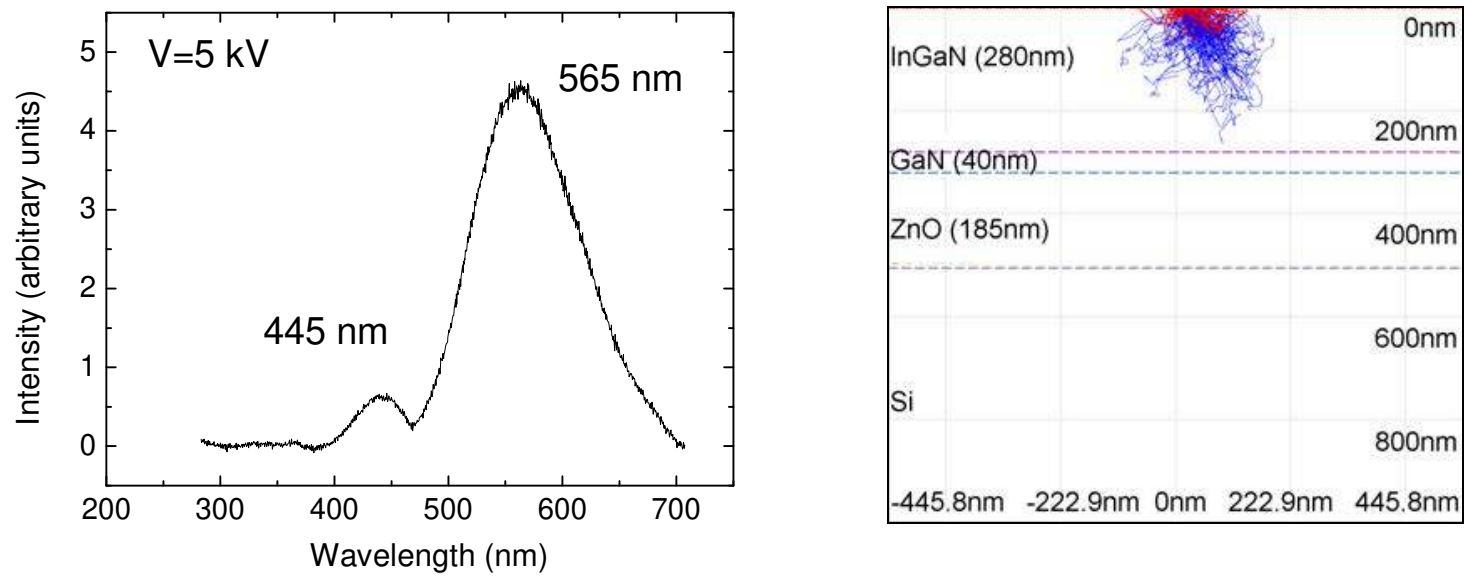

Figure 6. Normalized, RT, CL spectrum under $5 \mathrm{kV}$ accelerating voltage, plus a Monte Carlo simulation of the primary (red) and back-scattered (blue) electron diffusion.

The simulation suggested that an incident electron beam, with an energy of $5 \mathrm{kV}$, stimulated a response from most of the InGaN/GaN layer depth. The spectrum itself shows two peaks located at about $445 \mathrm{~nm}(2.79 \mathrm{eV})$ and $565 \mathrm{~nm}(2.20 \mathrm{eV})$. The first of these peaks was indexed as InGaN with an In concentration of about $17.5 \pm 5 \%$ [21], which is coherent with the value calculated from the XRD scan. The second (565 nm) peak has been observed in InGaN grown on bulk ZnO in the past and has been attributed to emission from Zn-related impurity centers in the InGaN [22]. This is coherent with the slight diffusion of $\mathrm{Zn}$ into the $\mathrm{InGaN} / \mathrm{GaN}$ near the interface with $\mathrm{ZnO}$, which was observed by SIMS.

Finally, the InGaN/GaN was lifted-off the substrate by immersion in dilute $\mathrm{HNO}_{3}$.

After several minutes, the $\mathrm{ZnO}$ dissolved completely and the InGaN/GaN separated from the substrate.

\section{CONCLUSIONS}

InGaN/GaN films were grown on ZnO-buffered Si (111) substrates by MOVPE. The dissociation of $\mathrm{ZnO}$ observed during conventional MOVPE growth of InGaN/GaN was combated through the use of a low pressure/temperature MOVPE approach with $\mathrm{N}_{2}$ as a carrier gas and DMHY added to the $\mathrm{NH}_{3}$ in order to facilitate atomic nitrogen production at lower temperatures. XRD, SEM, TEM, SIMS and CL characterisations showed smooth, highly c-axis oriented InGaN/GaN films having a well-defined interface with the $\mathrm{ZnO}$ underlayer, continuous lattice fringes across the interfaces and no evidence of any back-etching of $\mathrm{ZnO}$. XRD and CL suggest that between 17.5 and $21.5 \%$ of In was integrated in the GaN, without any phase separation. Slight $\mathrm{Zn}$ diffusion into the InGaN/GaN was observed near the interface with $\mathrm{ZnO}$.

Thus it was demonstrated that use of a PLD-grown $\mathrm{ZnO}$ buffer layer allows highly c-axis oriented wurtzite InGaN/GaN to be grown on $\mathrm{Si}$ substrates without removal of the amorphous $\mathrm{SiO}_{2}$ layer. Such an approach may open the way to the integration of InGaN based devices with Si-based 
electronics. The feasibility of chemical lift-off of the InGaN/GaN from the substrate was also demonstrated via dissolution of the $\mathrm{ZnO}$ in dilute $\mathrm{HNO}_{3}$. Such a wet-etching approach would allow wafer bonding of the InGaN/GaN onto alternative substrates, with advantages such as superior transparency, and/or electrical/thermal conductivity.

\section{ACKNOWLEDGEMENTS}

The authors would like to thank the French "Agence National de la Recherche" for financial support.

\section{REFERENCES}

[1] X. Duan, Y. Huang, Y. Cui, J. Wang, C. M. Lieber, Nature 409 (2001) 66.

[2] T. Mukai, S. Nakamura, M. Senoh, Appl. Phys. Lett. 64 (1994) 1687.

[3] N. Golego, S. A. Studenkin, M. Cocivera, J. Electrochem. Soc. 147 (2000) 1592.

[4] S. C. Jain, M. Willander, J. Narayan, R. Van Overstraeten, J. Appl. Phys. 87 (2000) 965.

[5] D. J. Rogers, F. Hosseini Teherani, A. Yasan, R. McClintock, K. Mayes, S.R. Darvish, P. Kung, M. Razeghi, G. Garry, Proc. SPIE 5732 (2005) 412.

[6] D. J. Rogers, F. Hosseini Teherani, A. Ougazzaden, S. Gautier, L. Divay, A. Lusson, O. Durand, F. Wyczisk, G. Garry, T. Monteiro, M. R. Correira, M. Peres, A. Neves, D. McGrouther, J. N. Chapman, M. Razeghi, Appl. Phys. Lett. 91 (2007) 071120.

[7] A. Ougazzaden, D. J. Rogers, F. Hosseini Teherani, T. Moudakir, S. Gautier, T. Aggerstam S. Ould Saad, J. Martin, Z. Djebbour, L. Divay, O. Durand, G. Garry, A. Lusson, D. McGrouther, J. N. Chapman, J. Cryst. Growth 310 (2008) 944.

[8] D. J. Rogers, F. Hosseini Teherani, F. Jomard, M. Molinari, M. Troyon, D. McGrouther, J. N. Chapman, T. Moudakir, S. Gautier, A. Ougazzaden, M. Razeghi, J. Vac. Sci. Technol. B 273 (2009) 1655.

[9] R. Paszkiewicz, B. Paszkiewicz, M. Wosko, A. Szyszka, L. Marciniak, J. Prazmowska, W. Macherzynski, J. Serafinczuk, J. Kozowski, M. Tlaczala, J. Kovac, I. Novotny, J. Skriniarova, D. Hasko, J. Cryst. Growth 310 (2008) 4891.

[10] S.-J. Wang, N. Li, E.-H. Park, S.-C. Lien, Z. C. Feng, A. Valencia, J. Nause, I. Ferguson, J. Appl. Phys. 102 (2007) 106105.

[11] J.-B. Huang, S.-S. Wei, L.-C. Chen, L.-S. Hong, Solid-State Electronics (2008), doi:10.1016/j.sse.2008.03.007.

[12] M. Benyoucef, M. Kuball, B. Beaumont, P. Gibart, Appl. Phys. Lett. 81 (2002) 2370.

[13] J.W Lee, S.W Park, J.B. Yoo, Phys. Stat. Sol. A 176 (1999) 583.

[14] S.J. An, W.I. Park, G.C. Yi, Y.J. Kim, H.B. Kang, M. Kim, Appl. Phys. Lett. 84 (2004) 3612.

[15] K. Black, A.C. Jones, P.R. Chalker, J.M. Gaskell, R.T. Murray, T.B. Joyce, S.A. Rushworth, J. Crystal Growth 310 (2008) 1010.

[16] A. Mircea, A. Ougazzaden, R. Mellet, Prog. Cryst. Growth Charact. 19 (1989) 39.

[17] S. Gautier, C. Sartel, S. Ould-Saad, J. Martin, A. Sirenko, A. Ougazzaden, J. Cryst. Growth 298 (2007) 428.

[18] F. Scholz, V. Harle, F. Steuber, H. Bolay, A. Dornen, B. Kaufmann, V. Syganow, A. Hangleiter, J. Crystal Growth 170 (1997) 321.

[19] M. Troyon, D. Pastre, J. P. Jouart, and J. L. Beaudoin, Ultramicroscopy 75 (1998) 15. 
[20] M. Suchea, S. Christoulakis, C. Tibeica, M. Katharakis, N. Kornilios, T. Efthimiopoulos, E. Koudoumas, Applied Surface Science, 254 (2008) 5475.

[21] S. Stepanov, W.N. Wang, B.S. Yavich, V. Bougrov, Y.T. Rebane, Y.G. Shreter, MRS Internet J. Nitride Semicond. Res. 6 (2001) 6.

[22] N. Li, S.-J. Wang, E.-H. Park, Z. C. Feng, A. Valencia, J. Nause, C. Summers, I. Ferguson, Proc. of SPIE Vol. 6669 (2007) 66690X-3. 